\title{
Optimasi Ekstraksi Dna Dari Spesimen Feses Pasien Kanker
} Kolorektal

\author{
Optimization of DNA Extraction from Stool Specimens from Patients with Colorectal \\ Cancer
}

\author{
Eustachius Hagni Wardoyo', Yunita Sabrina', Dewi Suryani' ${ }^{1}$, Ramses Indriawan² \\ ${ }^{1}$ Bagian Mikrobiologi, Fakultas Kedokteran Universitas Mataram, ${ }^{2}$ Bagian Bedah onkologi \\ RSUD Prov NTB/ Fakultas Kedokteran Universitas Mataram
}

Korespondensi Penulis:

Eustachius Hagni Wardoyo

Email : wardoyo.eh@unram.ac.id

\begin{abstract}
Abstrak
Latar Belakang: Pasien kanker kolorektal sering mengalami diare, baik itu karena konsekuensi langsung akibat penyakit, efek samping kemoterapi/radioterapi, atau karena adanya infeksi. Perubahan konsistensi feses pasien kolorektal dalam kemoterapi menyebabkan perubahan komposisi feses (jumlah sel bakteri, komposisi inhibitor) yang berbeda pada feses manusia normal. Konsekuensinya ekstraksi DNA bakterial dari feses pasien kanker kolorektal dalam kemoterapi perlu dilakukan optimasi. Tujuan penelitian untuk mendapatkan protokol DNA optimal dari feses cair pasien kolorektal. Metode: Ekstraksi DNA menggunakan Quick-DNA ${ }^{\mathrm{TM}}$ Fecal/Soil Microbe Miniprep Kit (Zymoresearch). Terdapat 3 pilihan protokol yang dilakukan, yang mana 2 protokol lainnya yang merupakan modifikasi dari protokol standar yang mengikuti prinsip: 1. Disrupsi mekanis untuk memisahkan sel bakteri dari materi feses dengan modifikasi lama sentrifugasi, 2. Proses binding DNA dengan modifikasi kecepatan sentrifugasi, 3. Proses mendapatkan DNA elusi dengan modifikasi gradien volume buffer DNA. Protokol standar diaplikasikan pada feses kontrol berpasangan usia dan jenis kelamin dan feses sampel, sedang 2 protokol lainnya diaplikasikan hanya pada feses sampel. Rasio absorbansi A260/280 $\geq 1.8$ menggunakan Nanodrop ${ }^{\mathrm{TM}} \mathrm{di}^{\mathrm{a}}$ aplikasikan pada konsentrasi DNA yang dinyatakan sebagai DNA murni. Pemeriksaan dilakukan sebanyak 3 kali dan reratanya dilaporkan dalam penelitian ini. Hasil: Rasio absorbansi sebesar A260/280 $\geq 1.8$ didapatkan pada protocol ketiga yakni dengan rerata rasio absorbansi A260/280 1.81, sedangkan pada protokol 2 dan 3 feses sampel menunjukkan rerata rasio absorbansi A260/280 1.79 dan 1.81 . Kesimpulan: Protokol ketiga dalam penelitian ini merupakan protokol optimal untuk ekstraksi DNA pada sampel feses pasien pasien kanker kolorektal paska keoterapi.
\end{abstract}

Kata kunci: ekstraksi DNA, feses diare, kanker kolorektal

\begin{abstract}
Background: Colorectal cancer patients often experience diarrhea as a direct consequence of the disease, as a side effect of chemotherapy/radiotherapy, or due to an infection. The change in stool consistency in colorectal patients in chemotherapy causes a change in the stool composition (bacterial cell count, inhibitor composition) that is different from the normal human stool composition. Consequently, the extraction of bacterial DNA from the stools of colorectal cancer patients in chemotherapy needs to be optimized. Aim to obtain an optimal protocol for DNA extraction from the loose stools of colorectal patients. Method: The DNA extraction was done using the Quick-DNA ${ }^{\mathrm{TM}}$ Fecal/Soil Microbe Miniprep Kit (Zymo Research). There were 3 protocol options that were implemented, 2 of which protocols were modified from the standard protocol that follows the principle of: 1. Mechanical disruption to separate bacterial cells from fecal matter by modifying the length of centrifugation, 2. DNA binding process by modifying the speed of centrifugation, 3. Process of obtaining eluted DNA by modifying the gradient of the volume of the DNA buffer. The standard protocol was applied to the stools of the age-and-sex paired controls and stool samples, while the other 2 protocols were applied only to the stool samples. The absorbance ratio of A260/280 $\geq 1.8$ using the Nanodrop ${ }^{\mathrm{TM}}$ was applied to the DNA concentration which was considered pure DNA. The test was conducted 3 times dan the mean is reported in this research. Results: The absorbance ratio of $A 260 / 280 \geq 1.8$ was found in the third protocol namely with a mean absorbance ratio of A260/280 1.81 , while in the second and third protocols the stool samples showed a mean absorbance ratio of
\end{abstract}


A260/280 1.79 and 1.81. Conclusion: The third protocol in this research is the optimal protocol for DNA extraction from the stool samples of the colorectal cancer patients after chemotherapy.

Keywords: DNA extraction, diarrheal stool, colorectal cancer

\section{Pendahuluan}

Diare persisten pada kanker kolorektal merupakan manifestasi yang sering ditemukan. Kondisi ini dapat disebabkan oleh 3 faktor: faktor kanker itu sendiri, efek samping terapi (antibiotika dan atau antineoplastik) dan faktor infeksi. (1) Diare yang disebabkan oleh kanker itu sendiri dapat berupa malabsorpsi garam empedu, overgrowth populasi bakteri tertentu dan gangguan refleks ileal brake suatu mekanisme feedback negatif untuk menentukan kecepatan perpindahan makanan. Diare yang diinduksi pemberian antineoplastik pada onset akut ( $\leq 24$ jam) merupakan diare yang berhubungan dengan dosis antineoplastik, modifikasi dosis, pemberian ajuvan antidiare merupakan antisipasi terhadap diare jenis ini.(2) Diare yang terjadi pada onset lanjutan $\geq$ 6 hari dengan siklus 3 mingguan dengan dosis tinggi atau 11 hari dengan siklus mingguan dengan dosis rendah memerlukan investigasi penyebab lebih lanjut. Diare yang diinduksi oleh antibiotika berhubungan erat dengan infeksi Clostridium difficile.

$$
\text { Keberadaan C. difficile dari }
$$
spesimen feses tanpa dilakukan pemeriksaan keberadaan toksin $\mathrm{A}$ dan atau B (tcdA - tcdB) tidak cukup sebagai diagnosis infeksi $C$. difficile. Pemeriksaan kultur sitotoksik Clostridium difficile sebagai pemeriksaan baku emas memerlukan seperangkat instrumen kultur sel pada kondisi anaerob yang mahal dan tidak mampu dilakukan pada laboratorium dengan kapasitas yang terbatas. Pemeriksaan molekuler dapat dilakukan sebagai diagnosis alternatif karena memiliki sensitivitas yang tinggi sebagai stand alone diagnosis. ${ }^{(3)}$

Ekstraksi DNA feses sebagai langkah awal pemeriksaan molekuler memerlukan prosedur yang disesuaikan dengan kondisi klinis pasien. Tantangan untuk mendapatkan DNA dari feses dari penelitian ini adalah spesimen feses pada pasien yang menjalani /pos terapi antibiotika dan atau antineoplastik memiliki karakteristik khas, setidaknya pada dua hal: 1. Terjadi penurunan populasi mikrobiota usus yang sensitif terhadap antibiotika dan atau antineoplastik yang diberikan dan digantikan dengan populasi mikrobiota yang resisten terhadap antibiotika, 2. Terjadi perubahan kondisi penghambat (terkait materi feses, perubahan $\mathrm{pH}$, degradasi sel epitel vili, metabolit 
antibiotika/antineoplastik dll) yang mengecilkan peluang mendapatkan jumlah DNA optimal. Berdasarkan uraian di atas perlu dilakukan optimasi Ekstraksi DNA dari spesimen feses pasien kanker kolorektal yang menjalani kemoterapi yang mempengaruhi konsentrasi DNA. ${ }^{(4)}$ (5)

\section{Metode}

Penelitian potong lintang dilakukan terhadap dua tipe sampel: feses kontrol dan feses sampel secara berpasangan. Feses control didapatkan pada pasien matching usia dan jenis kelamin pasien. Adapun feses sampel didapatkan dari pasien dengan : 1) Pasien dalam kemoterapi antineoplastik siklus mingguan yang mengalami diare pada hari $\geq 11$ (late onset diarrhea); 2) Pasien dalam kemoterapi antineoplastik siklus tiga mingguan yang mengalami diare pada hari $\geq 6$ (late onset diarrhea); 3) Pasien dalam kemoterapi antineoplastik siklus mingguan dan antibiotika yang mengalami diare pada hari $\geq 11$ (late onset diarrhea); 4) Pasien dalam kemoterapi antineoplastik siklus tiga mingguan dan antibiotika yang mengalami diare pada hari $\geq 6$ (late onser diarrhea); 5) Pasien dalam terapi antibiotika baik per oral atau parenteral atau riwayat terapi antibiotika dalam waktu kurang dari 12 minggu; 6) Setuju untuk menjadi subyek penelitian. Kriteria eksklusi: Pasien yang memenuhi kriteria inklusi dan tidak menyetujui untuk menjadi subyek penelitian. Optimasi ekstraksi DNA menggunakan kit komersial Quick-DNA $^{\mathrm{TM}}$ Fecal/Soil Microbe Miniprep Kit. ${ }^{(6)}$

Ekstraksi DNA dari Feses: Feses kontrol seberat 2 gram diambil sejumlah $50 \mathrm{mg}$ dan feses sampel sebanyak $50 \mathrm{ml}$ masing-masing dimasukan kedalam tabung lisis ZR BashingBead $^{\mathrm{TM}}$ terpisah yang telah diberi label kemudian mengikuti prosedur baku dari Quick-DNA ${ }^{\mathrm{TM}}$ Fecal/Soil Microbe Miniprep Kit. ${ }^{(6)}$ Kit komersial ekstraksi DNA yang dipilih merupakan Kit yang menggunakan prinsip filtrasi kolumn dalam separasi DNAnya. Protokol untuk feses normal dibuat gradient perlakuan (modifikasi perlakuan) dari protokol standar yang dibuat oleh pabrik yang disebut sebagai protokol pertama. Perlakuan sampel feses pre ekstraksi DNA: khusus untuk sampel feses adalah, pemilahan antara material feses dengan sel Bakteri yang cukup krusial, sehingga kit ekstraksi DNA bakteri dari jenis spesimen yang lain berbeda.Modifikasi protokol ekstraksi DNA: protokol kedua dan ketiga dibuat setelah aplikasi protokol standar dilakukan dan memberikan 
hasil yang berbeda antara feses kontrol dan feses sampel.

Isolasi DNA berasal dari sampel feses yang telah dikembangkan oleh produsen dan disebut sebagai "Protokol 1". Pada feses sampel perlu dipertimbangkan kondisi-kondisi sebagai berikut: konsistensi feses cairlembek, perubahan komposisi inhibitor PCR karena adanya obat kemoterapi, perubahan populasi microbiota usus yang mungkin berpengaruh pada komposisi dan konsentrasi DNA feses.

Zymoresearch membuat protocol ekstraksi DNA namun dapat diaplikasikan modifikasi protocol sesuai dengan kebutuhan peneliti. Pengembangan protocol ini ditujukan untuk mendapatkan kemurnian DNA yang dengan target A260/280 antara 1,8-2,0, semakin mendekati angka 2 maka kemurnian akan semakin baik. Modifikasi minor inilah yang kita sebut sebagai protocol 2 dan 3. Untuk mengembangkan protocol yang sesuai dengan kondisi feses sampel perlu memperhatikan prinsip-prinsip ekstraksi DNA pada sampel feses:

Tahap disrupsi mekanis dan tahap pengikatan DNA

Disrupsi mekanis merupakan tahapan pemisahan material seluler dengan material kotoran feses. Proses ini meliputi pelarutan menggunakan
PBS dan penghancuran material kotoran menggunakan kombinasi Teknik pengadukan bead dan sentrifugasi. Pengikatan DNA mengambil peran kritis dalam menentukan seberapa besar DNA yang bisa diambil diproses akhir. Pengambilan DNA menggunakan filter column dengan Teknik sentrifugasi bertujuan untuk mendapatkan DNA seoptimal mungkin. Dengan mempertimbangkan sumberdaya yang dimiliki, maka modifikasi teknik sentrifugasi ini dilakukan untuk mendapatkan nilai yang optimal. ${ }^{(7)(8)}$

Tahap elusi DNA

Langkah ini merupakan Langkah menurunkan DNA yang terjebak didalam filter column untuk dikoleksi ditabung koleksi menggunakan cairan elusi. Berhubung dengan target konsentrasi DNA optimum, volume elusi menjadi target modifikasi optimasi yang dimaksud. Adapun protokol kedua dan ketiga dapat dilihat pada tabel 1 berikut ini: 
Tabel 1. Protokol ekstraksi DNA dan modifikasinya. TA=tidak ada modifikasi

\begin{tabular}{|c|c|c|}
\hline No & Langkah Protokol 1 (Zymoresearch) & Modifikasi Protokol \\
\hline 1 & $\begin{array}{l}50 \mathrm{mg}(100 \mathrm{ml}) \text { feses masuk kedalam tabung lisis }+750 \\
\mu \mathrm{l} \text { buffer PBS }\end{array}$ & TA \\
\hline 2 & + Bead beater sentrifugasi maks selama $\geq 5$ menit & TA \\
\hline 3 & Sentrifugasi $10.000 \times \mathrm{g} 1$ menit & $\begin{array}{l}\text { Protokol 2:sentrifugasi } 11.000 \text { x } \\
\text { g selama } 30 \text { detik } \\
\text { Protokol } 3 \text { : sentrifugasu } 11.000 \\
\text { xg selama } 1 \text { menit }\end{array}$ \\
\hline 4 & $\begin{array}{l}\text { Transfer } 400 \mu \text { l supernatan ke tabung filter dan tabung } \\
\text { koleksi sentrifugasi } 8.000 \times \mathrm{g} 1 \text { menit }\end{array}$ & TA \\
\hline 5 & $+1.200 \mu \mathrm{l}$ buffer lisis genomik ke dalam filtrat diatas & TA \\
\hline 6 & $\begin{array}{l}\text { Pindah } 800 \mu \mathrm{l} \text { kedalam tabung kolum dan tab koleksi } \\
\text { spin } 10.000 \times \text { g selama } 1 \mathrm{mnt}\end{array}$ & $\begin{array}{l}\text { Protokol 2: sentrifugasi } 11.000 \text { x } \\
\text { g selama } 30 \text { detik } \\
\text { Protokol 3: sentrifugasu } 12.000 \\
\text { xg selama } 30 \text { detik }\end{array}$ \\
\hline 7 & Buang filter dari tab koleksi, ulang langkah diatas & TA \\
\hline 8 & $\begin{array}{l}\text { Cuci sebanyak } 2 \times \text { menggunakan } 200 \mu \text { l buffer prewash } \\
\text { DNA dan } 500 \mu \text { l buffer Wash DNA, spin } 10.000 x g \\
\text { selama } 1 \text { menit }\end{array}$ & TA \\
\hline 9 & $\begin{array}{l}\text { Pindahkan spin kolum ke dalam tab mikrosentrifugasi } \\
1,5 \mathrm{ml} \text { dan tambahkan } 100 \mu \mathrm{l} \text { buffer elusi DNA ke } \\
\text { kolum, spin } 10.000 \times \mathrm{xg} \text { selama } 30 \text { detik }\end{array}$ & $\begin{array}{l}\text { Protokol 2: volume buffer elusi } \\
110 \mu \mathrm{l} \\
\text { Protokol 3: volume buffer elusi } \\
120 \mu \mathrm{l}\end{array}$ \\
\hline 10 & $\begin{array}{l}\text { Tempatkan tab filter ke dalam tab koleksi dan } \\
\text { tambahkan } 600 \mu \text { l prep solution. Spin } 8,000 \times \text { selama } 3 \\
\text { menit }\end{array}$ & TA \\
\hline
\end{tabular}

Pengukuran DNA menggunakan rasio absorbansi 260: 280 (A260/A280). Absorbansi 260 merupakan absorbansi yang terbaik untuk estimasi konsentrasi dsDNA dalam arti sensitivitasnya. Meski demikian tidak hanya dsDNA yang terbaca dengan baik pada panjang gelombang tersebut, demikian juga RNA. Asam amino aromatik terserab dengan baik pada panjang gelombang 280nm. Keberadaan guanidine juga meningkatkan absorbansi pada $260 \mathrm{~nm}$.

Untuk mengevaluasi kemurnian DNA, pengukuran absorbansi dengan rentang antara $230 \mathrm{~nm}$ hingga $320 \mathrm{~nm}$ dapat dipergunakan untuk mendeteksi kemungkinan adanya kontaminan. Kemurnian DNA yang umum dipergunakan adalah rasio absorbansi 260nm dibagi dengan pembacaan pada 280nm (rasio A260/280). Kualitas DNA yang terbaik akan dicapai pada rasio antara 1.7-2.0. Instrumen yang dipergunakan adalah Nanodrop ${ }^{\circledR}$ (ThermoScientific). Pengukuran masing-masing absorbansi dilakukan sebanyak tiga kali. Adapun langkah pemeriksaan sebagai berikut: membuka tutup probe, bersihkan probe menggunakan tissue yang dibasahi alcohol 70\%, meneteskan cairan blangko (Normal saline solution) sebanyak $3 \mu \mathrm{l}$, tutup probe, pilih jenis 
absorbansi (260nm atau 280nm), tunggu beberapa saat akan terbaca angka absorbansi, membuka tutup probe, bersihkan probe menggunakan tissue yang dibasahi alcohol $70 \%$, meneteskan cairan sampel sebanyak 3 $\mu$, tutup probe, pilih jenis absorbansi (260nm atau $280 \mathrm{~nm}$ ), tunggu beberapa saat akan terbaca angka absorbansi

\section{Hasil}

Dalam penelitian ini feses sampel diperoleh dari seorang perempuan usia 42 tahun dengan diagnosis kanker kolorektal, 3 hari paska pemberian kemoterapi dan feses sesuai dengan Bristol Chart Stool 6 sebagai feses sampel. Feses kontrol diperoleh dari seorang perempuan usia 42 tahun sehat dan feses sesuai dengan Bristol Chart Stool 5. Pada pemeriksaan makroskopis feses sampel didapatkan karakteristik konsistensi feses lembek, berwarna kuning kecoklatan, tidak tampak adanya darah, tidak ada lendir, tampak adanya beberapa sisa makanan yang tidak tercerna (minimal). Karakteristik feses kontrol adalah konsistensi padat, berwarna coklat kekuningan, tidak ada lendir dan darah.

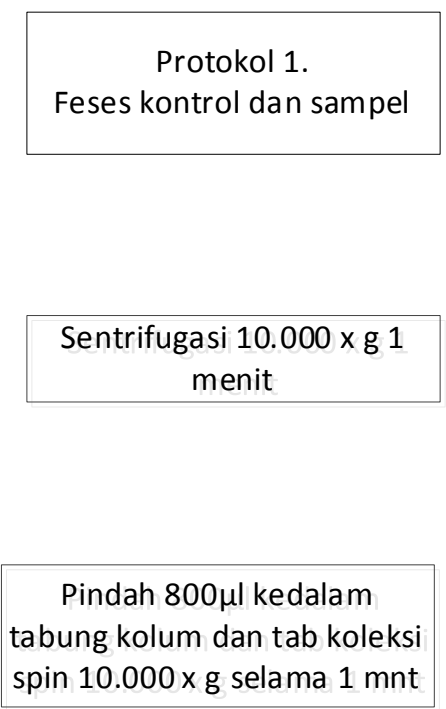

Pindahkan spin kolum ke dalam tab mikrosentrifugasi 1,5 $\mathrm{ml}$ dan tambahkan $100 \mu \mathrm{l}$ buffer elusi DNA ke kolum, spin $10.000 x$ selama 30 detik

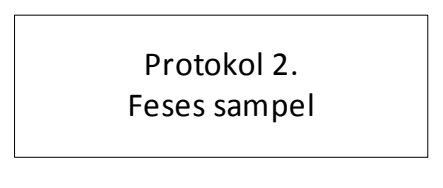

Mechanical

Disruption

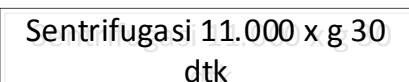

$\mathrm{dtk}$

\section{DNA binding}

Pindah $800 \mu$ l kedalam tabung kolum dan tab koleksi spin $11.000 \times$ g selama $30 \mathrm{dtk}$

\section{Elusi DNA}

Pindahkan spin kolum ke dalam tab mikrosentrifugasi $1,5 \mathrm{ml}$ dan tambahkan $110 \mu \mathrm{l}$ buffer elusi DNA ke kolum, spin $10.000 x g$ selama 30 detik

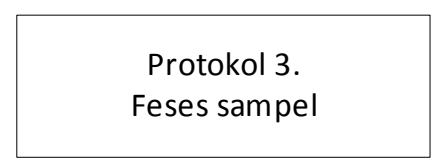

Sentrifugasi 11.000 x g 1 menit
Pindah $800 \mu l$ kedalam tabung kolum dan tab koleksi spin $12.000 \times$ g selama $30 \mathrm{dtk}$
Pindahkan spin kolum ke dalam tab mikrosentrifugasi $1,5 \mathrm{ml}$ dan tambahkan $120 \mu \mathrm{l}$ buffer elusi DNA ke kolum, spin $10.000 x g$ selama 30 detik

Gambar 1. Pengembangan protokol 2 dan 3 yang berasal dai protokol 1 (protokol standar). Fokus pada modifikasi yang dilakukan 
Pada penelitian ini, pengukuran DNA yang dilakukan setelah ekstraksi (sebelum dilakukan multiplikasi DNA) sulit untuk dinilai efisiensinya, karena pada rendahnya rasio konsentrasi DNA dibandingkan dengan kemungkinan kontaminan. Gejala ini dapat terlihat dari varian amplitudo pengukuran yang cukup besar antar pengukuran pada satu sampel yang sama. Justifikasi yang dipergunakan kemudian adalah menggunakan rasio A260/280 $\geq 1,8 \mathrm{~s} / \mathrm{d}$ 2. Pengukuran absorbansi pada penelitian ini adalah menggunakan Nanodrop ${ }^{\mathrm{TM}}$. Pengukuran dilakukan sebanyak tiga kali dan diambil reratanya

Tabel 2. Pengukuran Nanodrop. Masing-masing sampel diukur sebanyak 3 kali. Hasil yang ditampilkan adalah rasio absorbansi A260/280.

\begin{tabular}{|c|c|c|c|c|}
\hline Pengukuran & Feses kontrol & Feses sampel & Feses sampel & Feses sampel \\
\hline Protokol & & 1 & 2 & 3 \\
\hline Pengukuran 1 & 1,98 & 1,88 & 1,82 & 1,85 \\
\hline Pengukuran 2 & 1,82 & 1,77 & 1,78 & 1,75 \\
\hline Pengukuran 3 & 1,84 & 1,69 & 1,77 & 1,83 \\
\hline Rerata & $1,9 \pm 0,08$ & $1,78 \pm 0,1$ & $1,79 \pm 0,02$ & $1,81 \pm 0,05$ \\
\hline
\end{tabular}

\section{Pembahasan}

Kanker kolorektal dapat secara langsung menyebabkan perubahan konsistensi feses akibat reaksi inflamasi yang ditimbulkan. Konsistensi feses yang menjadi lebih lembek dari sebelumnya. Episode diare paska kemoterapi jarang didapatkan di RS, karena pasien paska kemoterapi biasanya dipulangkan. Cukup sulit untuk mendapatkan pasien kanker kolorektal dengan diare post kemoterapi

\section{Pemilihan metode ekstraksi}

Ekstraksi DNA dari feses kontrol menggunakan protokol pertama menunjukan hasil yang memuaskan dengan rerata 3 pengukuran pada rasio absorbansi A260/280 1,9, yang berarti sudah optimum. Sedangkan pada feses sampel rerata 3 pengukuran pada rasio absorbansi A260/280 1,78 yang berarti masih dibawah cut off yang ditetapkan. Sehingga dikembangkanlah variasi protokol 1 menjadi protokol 2 dan 3 yang sudah dijelaskan sebelumnya. Hal tersebut penting mengingat komposisi feses sampel pasien kolorektal yang tidak sama dengan feses kontrol. Pemeriksaan DNA bakteri dari feses pasien kanker kolorektal bermanfaat dalam melihat komposisi mikrobiota usus pasien kanker kolorektal maupun diagnosis diare dengan penyebab infeksi bakterial (E. coli, Clostridium 
difficile, Salmonella typhi dan Shigella dysentriae).

Modifikasi kecepatan dan kecepatan sentrifugasi pada tahap disrupsi mekanik

Kecepatan sentrifugasi $\begin{array}{r}\text { pada } \\ \text { tahapan disrupsi } \\ \text { mempengaruhi kualitas }\end{array}$
material sel dan material kotoran. Pada
proses ini tidak ada kecepatan ataupun
lama yang ideal kecuali dilakukan
ujicoba pada berbagai variasi
kecepatan dan lama sentrifugasi.

Modifikasi kecepatan dan kecepatan sentrifugasi pada tahap pengikatan DNA

Pengikatan DNA dilakukan dengan proses filtrasi pada tabung kolum filtrat. Semakin cepat putaran sentrifuge maka semakin cepat pula material seluler (sitoplasma, membrane sel yang terlarut) terpisah dimana materi DNA terfiltrasi dalam filtrat dan yang lain masuk ke dalam tabung koleksi. Lama sentrifugasi mempengaruhi waktu separasi antara material DNA dan material seluler tersebut tercapai. Berhubungan dengan jenis feses sampel dengan karakteristik khusus, optimasi juga dicoba dalam beberapa kecepatan dan lama sentrifugasi. ${ }^{(7)(8)}$

\section{Modifikasi volume buffer elusi}

Elusi buffer DNA merupakan buffer yang didesain khusus untuk mengikat DNA karena ikatan kovalen, tarik menarik ionic dan material lain yang dipilih oleh pabrik. Keberhasilan modifikasi volume elusi buffer sangat bergantung pada seberapa kuat kemampuan cairan elusi menarik DNA yang terperangkap di filter tabung, rasio jumlah DNA dan volume cairan buffer dan kemungkinan sisa pengganggu lain yang ikut terperangkap dalam filter. ${ }^{(9)(10)}$ Sepanjang pengetahuan penulis publikasi terkait dengan optimasi ekstraksi DNA dari feses pasien kanker belum pernah dilakukan, penelitian optimasi ekstraksi DNA feses yang dilakukan oleh Mathay et al (2015) menggali aspek optimasi volume feses yang dipergunakan, volume cairan supernatant, tabung transportasi, keperluan pendinginan dan bahan pengawet. ${ }^{(11)}$ Penelitian oleh Fiedorová et al (2019) melakukan komparasi 6 kit ekstraksi DNA dari feses komersial yang tersedia di pasaran. ${ }^{(12)}$

Penelitian metode ekstraksi merupakan bagian dari pemeriksaan pendahuluan mendapatkan material DNA murni seperti Polymerase Chain Reaction. Beberapa kondisi yang memiliki potensi menurunkan kemampuan kit ekstraksi DNA bakteri pada pasien kanker kolorektal post kemoterapi adalah: 
terdapat peluang peningkatan secara relatif komposisi inhibitor PCR akibat keberadaan obat kemoterapi, maupun sel epitel lumen usus, terdapat perubahan dinamika komposisi bakteria usus yang dapat berdampak langsung maupun tidak langsung terhadap proses ekstraksi DNA, terdapat perubahan konsistensi feses yang yang dapat berdampak langsung maupun tidak langsung terhadap proses ekstraksi DNA.

\section{Kesimpulan}

1. Pada protokol standar didapatkan rerata rasio absorbansi A260/280 pada feses kontrol 1.9 dan feses sampel 1.78, sedangkan pada protokol 2 dan 3 feses sampel menunjukkan rerata rasio absorbansi A260/280 1.79 dan 1.81

2. Rasio absorbansi $A 260 / 280 \geq 1.8$ didapatkan pada protokol 3 yakni dengan rerata rasio absorbansi A260/280 1.81

\section{Ucapan terima kasih}

Penelitian ini didanai melalui skema penelitian PNBP Fakultas Kedokteran Univeristas Mataram tahun 2019.

\section{Daftar Pustaka}

1. Mayo Clinic. Diare: Cancer-related cause and how to cope [Internet]. 2019 [cited 1BC Jan 20]. Available from: https://www.mayoclinic.org/ diseases-conditions/cancer/indepth/diarrhea/art-20044799

2. Neemann K, Freifeld A. Clostridium difficile-associated diarrhea in the oncology patient. Journal of Oncology Practice. 2017.

3. Crobach MJT, Dekkers OM, Wilcox $\mathrm{MH}$, Kuijper EJ. European Society of Clinical Microbiology and Infectious Diseases (ESCMID): Data review and recommendations for diagnosing Clostridium difficileinfection (CDI). Clinical Microbiology and Infection. 2009.

4. McDonald LC, Gerding DN, Johnson S, Bakken JS, Carroll KC, Coffin SE, et al. Clinical Practice Guidelines for Clostridium difficile Infection in Adults and Children: 2017 Update by the Infectious Diseases Society of America (IDSA) and Society for Healthcare Epidemiology of America (SHEA). Clin Infect Dis. 2018;66(7):987-94.

5. Department of Health U. Update guidance on the diagnosis and report of Clostridium difficile. Guid Diagnosis Report Clostridium difficle Infect. 2012; 
6. Zymo Research. Instruction ManualQuick DNA Miniprep Kit. Zymo Res Corp. 2018;

7. G.A. Kowalchuk, F.J. de Bruijn, I.M. Head ADLA. Molecular Microbial Ecology Manual. Dordrecht: Kluwer; 2004.

8. Strohmeier O, Keller M, Schwemmer F, Zehnle S, Mark D, Von Stetten F, et al. Centrifugal microfluidic platforms: advanced unit operations and applications. Chem Soc Rev. 2015;

9. Shan $G$, Jin W, Lam Ek, Xing $X$. Purification of total DNA extracted from activated sludge. J Environ Sci. 2008;

10. BioRad. NanoDrop 1000 Spectrophotometer V3 . 8 User' $s$ Manual. No J. 2012;

11. Mathay C, Hamot G, Henry E, Georges L, Bellora C, Lebrun L, et al. Method optimization for fecal sample collection and fecal DNA extraction. Biopreserv Biobank. 2015;

12. Fiedorová $K$, Radvanský $M$, Němcová $E$, Grombiříková $H$, Bosák J, Černochová $M$, et al. The impact of DNA extraction methods on stool bacterial and fungal microbiota community recovery. Front Physiol. 2019; 